\title{
A Review of the Epidemiology of Gastrointestinal Nematode Infections in Sheep and Goats in Ghana
}

\author{
Seth Blackie ${ }^{1}$ \\ ${ }^{1}$ Central University College, Accra, Ghana \\ Correspondence: Seth Blackie, Central University College, Accra, Ghana. E-mail: sethamoblackie@yahoo.com
}

Received: January 13, 2014 Accepted: February 11, 2014 Online Published: March 15, 2014

doi:10.5539/jas.v6n4p109 URL: http://dx.doi.org/10.5539/jas.v6n4p109

\begin{abstract}
In this paper, the gastrointestinal nematode parasites infecting small ruminants (sheep and goats) in Ghana and the epidemiological factors influencing their prevalence are reviewed and discussed. Twelve nematode species belonging to six families have been reported to infect these livestock in the country with Haemonchus contortus being the most prevalent helminth parasite in both animals. Parasitic gastroenteritis is caused by mixed infection of several nematode species. Management /husbandry practices, climate and host influence are found to be the main factors that affect gastrointestinal nematode infections in sheep and goats. Seasonal changes in the level of infective strongylate nematode larvae on pasture in the different agro-ecological zones of Ghana are reviewed. The number of infective larvae on pasture is reported to be directly related to the pattern of rainfall. Consequently, rainfall could be relied on to predict the rate of transmission of infection in grazing animals. Finally, the relevance of epidemiological knowledge in the development of efficient measures for controlling gastrointestinal nematode infections in sheep and goats in Ghana is discussed.
\end{abstract}

Keywords: gastrointestinal nematodes, small ruminants, epidemiology, agro-ecological zone, host factors, Ghana

\section{Introduction}

Helminth infections remain one of the most important diseases limiting small ruminant production in tropical Africa (FAO, 1992). About $95 \%$ of sheep and goats are reported to be infected with helminths with Haemonchus and Trichostrongylus being the key species involved (Rey, 1991). Production losses through mortality and reduced weight gain have been reported by several authors (Oduro, 1972; Schillhorn van Veen, 1973; Allonby \& Urquhart 1975; Fabiyi, 1987; Bekele et al., 1992; Nwafor, 2004). Strongyle nematodes are the main cause of parasitic gastroenteritis (PGE) in sheep and goats in Ghana (Agyei \& Amponsah, 2001). The epidemiology and pathogenesis of many strongyle infections of grazing animals are very similar. Sheep and goats are infected by ingesting infective larvae (L3), which develops to L4 and adult stages in the gastric or intestinal mucosa (Demeler, 2005; Roeber et al., 2013). Disease is caused by the L4 and/or adult stages and depends on factors including: species of nematode infecting the host; intensity of the infection; species, age and immunological/ health status of the host; host response against the parasite; environment and management aspects (Assoku, 1981; Kassai, 1999; Taylor et al., 2007; Roeber et al., 2013). The prepatent period is normally 2-3 weeks, although it may be more than 6 months for certain species or if development is "arrested" (Michel, 1974; Eysker, 1993). Rainfall is considered to be the main climatic factor determining the availability of infective strongylid larvae and the transmission of infection in grazing animals (Chiejina et al., 1989; Fakae, 1990; Agyei \& Amponsah, 2001; Agyei, 2003; Agyei et al., 2005). This paper reviews the epidemiological knowledge of gastrointestinal (GI) nematode infections in sheep and goats in the different agro-ecological zones of Ghana with the view to providing adequate information for developing strategic control measures against GI nematode infections in small ruminant in Ghana.

\section{Species of Nematodes Found in the Gastrointestinal Tract of Sheep and Goat in Ghana}

GI nematode infections in Ghana have been reported by several authors (Beal, 1929; Edwards \& Wilson, 1958; Jackson, 1965; Dolu, 1972; Naate, 1973; Oppong, 1973; Assoku, 1981; Agyei, 1997, 2003; Agyei \& Amponsah, 2001). PGE in sheep and goats is caused by mixed infections of several nematode species. Twelve GI nematodes species belonging to six families have been reported to infect sheep and goats in Ghana (Table 1). The most prevalent genera of GI nematodes reported in order of prevalence are: Haemonchus, Trichostronglyus. Oesophagostomum and Cooperia (Agyei \& Amponsah, 2001). The life cycles of these nematodes follow a similar pattern, with some exceptions (e.g., Nematodirus spp., for which larval development occurs within the egg) 
(Figure 1) (Levine, 1968). Adult worms in the digestive tract produce eggs that are passed in the faeces on to pasture. The reproductive potential of different gastrointestinal nematode species varies quite significantly. Females of Haemonchus contortus may lay over 10,000 eggs a day whilst Oesophagostomum and Charbetia produce between 5000-1000 eggs/female/day. Females of Teladorsagia and Trichostrongylus spp. are less fecund with an average egg production of 100-200 eggs per female per day (Hanson \& Perry, 1994). Under favourable conditions, the eggs will hatch into first and second stage larvae and feed on bacteria in the faeces until finally the infective stage L3 is reached. First, second and third-stage larvae (L1, L2 and L3, respectively) are free-living in the environment. The fourth larval (L4) and adult stages (dioecious) are parasitic in the gastrointestinal tract of the host (Demeler, 2005). The development to L3 is temperature dependent and may be as rapidly as 3 days under tropical conditions (Sani et al., 1995).

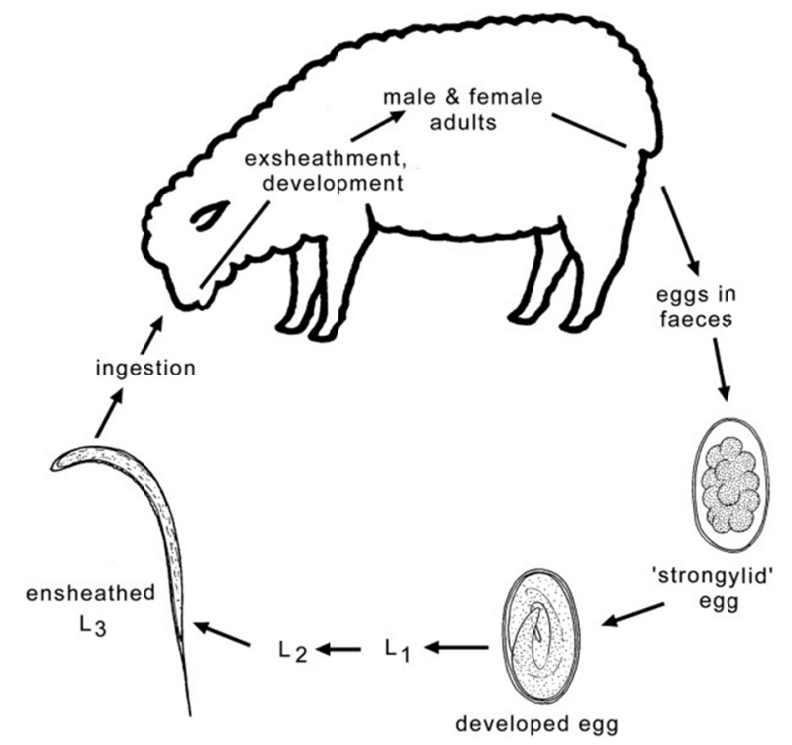

Figure 1. Life cycle representing gastrointestinal nematodes of small ruminants-Adapted from (Demeler, 2005)

Table 1. Gastrointestinal nematode species reported in sheep and goats in Ghana

\begin{tabular}{llll}
\hline Family* & Species** & Host species** affected & Location in the host* \\
\hline Trichostrongylidae & Haemonchus contortus & Sheep and Goats & Abomasum \\
& Ostertagia circumcincta & Sheep and Goats & Abomasum \\
& Trichostrongylus axei & Sheep and Goats & Abomasum \\
& Trichostrongylus colubriformis & Sheep and Goats & Small intestine \\
& Cooperia curticei & Sheep and Goats & Small intestine \\
& Ostertagia mashali*** & Sheep & Large intestine \\
Chabertiidae & Chabertia ovina & Sheep and Goats & Large intestine \\
& Oesophagostomum columbianum & Sheep and Goats & Large intestine \\
Strongyloididae & Strongyloides papillosus & Sheep and Goats & Small intestine \\
Ancylostomatidae & Gaigeria pachyscelis & Sheep and Goats & Small intestine \\
Molineidae & Nematodirus filicolis & Sheep & Small intestine \\
Trichuridae & Trichuris ovis & Sheep and Goats & Large intestine \\
\hline
\end{tabular}

Adapted from *Rahmann \& Seip (2006); Roeber et al. (2013); **Assoku (1981). *** Lichtenfels and Pilitt (1989) identified this Mashallagia marshalli. 
Susceptible animals are infected by ingestion of the infective third stage larvae L3. Depending on species development to the adult stage occurs either in the abomasum or in the small intestine after two moults. For most species development to the adult stage takes between 2-3 weeks. Development may also be 'arrested' or 'inhibited' at a specific parasitic stage, usually the early fourth stage (EL4). In a number of species, but particularly in Haemonchus and Teladorsagia, it represents a seasonal phenomenon, enabling the parasite to survive unfavourable conditions such as winter or a dry season. However, inhibited development may also be associated with host resistance (Eysker, 1993).

\section{Development and Survival of Free-Living Stages in the Environment}

The development and survival of free-living stages of GI nematodes of small ruminants are influenced mainly by environmental temperature and humidity with the effects of pasture conditions playing a significant role (O'Connor et al., 2006). These researchers reported that early in the free-living phase, the developmental success of Haemonchus contortus, Teladorsagia circumcincta and Trichostrongylus colubriformis is limited by susceptibility to cold temperatures with $H$. contortus being most susceptible, followed by $T$. colubriformis and then $T$. circumcincta. They observed that the length of the development cycle is dependent largely on temperature, with development rate increasing at warmer temperatures. However, addition of moisture is generally required for development to proceed to the infective larval stage. H. contortus was found to be most susceptible to desiccation during the pre-infective stages. Once the infective stage is reached, the influences of temperature and moisture on survival are less important, resulting in considerable survival times under conditions lethal to pre-infective stages. However, hot, dry conditions can be lethal for infective larvae of all three species, while extreme cold is also lethal with significant species variation (O'Connor et al., 2006). On the contrary, Ostertagia, and Nematodirus have been reported to show a strong adaptation to low temperatures. Nematodirus larvae are able to survive to winter inside the egg shell (Manfredi, 2006). Larvae may be protected from desiccation for a time by the crust of the faecal pat in which they lie or by migrating into the soil. Many biological factors contribute to disperse the larvae on the pasture. Dung burying beetles, coprophagous beetles and earthworms can greatly reduce the larvae of some trichostrongylids on pasture as they contribute to the spread of the faecal material on the pasture and allow the larval death as a consequence of drying (Manfredi, 2006).

\section{Factors Influencing Gastrointestinal Nematode Infection in Sheep and Goats}

\subsection{Climate}

In the permanently humid and savanna zones of the tropics, rainfall is the major factor determining the availability and transmission of strongylid nematodes in sheep and goats on natural pastures (Okon \& Enyenihi, 1975, 1977; Ogunsusi, 1979). Ghana is divided into six major agro-ecological zones (Table 2). The forest, transitional and coastal savanna zones, which lie in the southern parts of the country, are characterized by two rainy seasons falling from March-July and September - October, except for the forest zone where the minor rainy season extends to November, with a short dry season whilst the Guinea and Sudan savanna zones in the northern parts have one rainy season (May - Sept.) with a prolonged dry season. The mean monthly temperature over most parts of the country never falls below $25^{\circ} \mathrm{C}$ (Dickson \& Benneh, 1988; Benneh et al., 1990).

The seasonal influence on GI nematode egg counts and on the availability of infective strongylate larvae (L3) on pastures has been reported in the various agro-ecological zones of Ghana. In the forest zone with annual rainfall above $2000 \mathrm{~mm}$ (Table 2), L3 are found on pasture throughout the year however the number varies month by month. The level of L3 starts to pick up at the beginning of the rains in March and reaches a peak in June (the peak of the rainy season), but declines in July until November. It rises again in December only to fall in January and fluctuates between February and April (Agyei \& Amponsah, 2001). The presence of L3 on pasture throughout the year in the forest zones of Ghana reported by Agyei and Amponsah (2001) agrees with the observations by Hammond and Sewell (1991), who found that in the humid tropics where the annual rainfall is between $1000-2000 \mathrm{~mm}$ with a short dry season the microclimate is always suitable for the development and survival of the infective larvae. The level of infective larvae on pasture in this zone therefore remains relatively constant throughout the year. The stocking rate in the forest zone is therefore an important factor in determining the level of challenge. Adult sheep and goats are capable of building up some resistance but young stock are very susceptible to gastrointestinal helminths (Assoku, 1981; Chiejina, 1986).

Similarly, in the coastal and the transitional savanna regions, the population of infective larvae on pastures increases to a maximum during the rainy season, which coincides with the peak in feacal egg counts (FECs). However, in the coastal savanna regions no infective larvae are found on pasture during parts of the dry season (January and February) (Agyei, 1997); and in the transitional savanna regions infective larvae are absent on pasture from November to February during the dry season (Agyei et al., 2005). The mean annual rainfall in the 
coastal and transitional savanna zones is comparatively lower than that of the forest zone (Table 2) and it is obvious that in the former zones, lack of adequate moisture on pasture during some periods of the dry season prevents the development and translation of worm eggs into infective larvae (Sprent, 1946; Lee et al., 1960; Durie, 1962).

In the Guinea savanna regions with only one rainy season, fluctuating low levels of worm egg output in lambs and kids have been reported during the prolonged dry season from January to April and October to December. It has been found that worm eggs deposited during the prolonged dry season, in this climatic zone, do not develop to infective stage and development of new infections does not occur after the cessation of the rains early in October. However, transmission of infection continues until late in November due to the persistence of infective larvae on pastures. Pastures are free of infection from December to the start of the rains in May and hypobiosis (inhibited development of early fourth stage-EL4) is a means by which Haemonchus survives the dry season and re-infest pasture at the onset of the rains. Then as the rain progresses the climate become increasingly favourable for the free living stages (Ogunsusi, 1979; Agyei et al., 2005). Worm egg count starts to rise at the onset of the rains in May and reaches a peak in June but declines in July until September. It rises again in October and thereafter declines to low levels during the dry season (Agyei et al., 2005). It has been found that lambs and kids born during the dry season remain uninfected until the onset of the rains when the young animals become susceptible. However, if the nutrition of the young animals is good, they may withstand initial infection and develop some resistance (Hammond \& Sewell, 1991).

The reports by Agyei (1997), Agyei and Amponsah (2001) and Agyei et al. (2005) indicate that significant positive relationship exists between the level of herbage infective larvae and rainfall. This relationship supports the view that rainfall could be used to predict the level of infective larvae on pasture. Grazing animals would therefore be more susceptible to worm infections during the rainy season. This knowledge is important in the development of strategic interventions for the control of nematode infection in sheep and goats in Ghana.

Table 2. Climates of the agro-ecological zones

\begin{tabular}{lllll}
\hline $\begin{array}{l}\text { Agro-ecological } \\
\text { zone }\end{array}$ & $\begin{array}{l}\text { Mean annual rainfall } \\
(\mathbf{m m})\end{array}$ & $\begin{array}{l}\text { Range } \\
(\mathbf{m m})\end{array}$ & $\begin{array}{l}\text { Major rainy } \\
\text { season }\end{array}$ & $\begin{array}{l}\text { Minor rainy } \\
\text { season }\end{array}$ \\
\hline Rain forest & 2200 & $800-2800$ & March- July & $\begin{array}{l}\text { Sept.-Nov. } \\
\text { Deciduous forest }\end{array}$ \\
$\begin{array}{ll}\text { Transitional zone } \\
\text { Coastal savanna }\end{array}$ & 1500 & $1200-1600$ & March- July & Sept.-Oct. \\
Guinea savanna & 1000 & $1100-1400$ & March- July & Sept -Oct. \\
Sudan savanna & 1000 & $600-1200$ & March- July & Sept.-Oct. \\
\hline Source: Acapted & $800-1200$ & May - Sept & \\
\hline
\end{tabular}

Source: Adapted from data from the Meteorological Department, Legon, Accra, Ghana.

\subsection{Management and Husbandry Practices}

The prevalence of GI nematode infections in small ruminants are also influenced by management systems and husbandry practices (Assoku, 1981). The system of sheep and goat production in Ghana is mainly traditional except for a few modern systems mostly associated with government and research institutions. The traditional system is common in the rural areas with intense agricultural activity. Three feeding systems are found within the traditional system: Free range grazing; Stall feeding or zero grazing; and tethering. A common characteristic of these feeding systems is that the animals are kept under unhygienic conditions and depend mainly on forage from poor natural pastures with very little input of feed supplement with virtually no anthelmintic treatment (Ockling, 1987). Malnutrition, poor growth rate and heavy worm burden have been reported in sheep and goats kept under the traditional system of production in sub Saharan Africa (Kusiluka \& Kambarag, 1996). Studies by Notifor et al. (2013) on the prevalence of gastrointestinal tract parasites in animals kept under different traditional management systems showed that prevalence were higher in tethered animals $(88.7 \%)$ followed by free range grazing animals $(60.9 \%)$. Animals confined in paddocks had the least prevalence $(45.5 \%)$. It is recommended that control measures should make use of the variation in helminth prevalence and intensity among management systems and age groups to achieve a rational use of anthelmintics. In addition, grazing spot should be rotated to reduce the chances of ruminants being re-infected with contaminated pastures (Notifor et al., 2013). 
In the modern system of small ruminant production, the animals are either stall fed or grazed on improved pastures often in combination with beef cattle and receive regular feed supplementation such as concentrates. In addition they receive regular anthelmintic treatment at the onset of the dry season or at the beginning of the rainy season (Ockling, 1987). Such strategic anthelmintic treatment has been shown to reduce worm burden and increase productivity in the modern system of production (Thomas \& Bell, 1988; Agyei, 1991; Nwafor, 2004). It is also known that alternating sheep and cattle every sixth month has proved successful in controlling helminth infections in both species as worm burdens in the hosts and the level of pasture contamination were both reduced (Barger \& Southcott, 1975).

Differences in the prevalence and intensity of GI nematode infections between the traditional and modern system of small ruminant production in Ghana has been demonstrated by Assoku (1981). His study showed that sheep kept under rotational or restricted grazing (semi-intensive) system of management had fever worm egg counts $(\mathrm{P}<0.01)$ than those kept under the free-range grazing or extensive system (Table 3). It is evident that routine prophylactic drenching at regular intervals with different anthelmintics has a significant lowering effect on the total worm burden.

Table 3. The Effect of the type of management/ husbandry practices on the mean worm-egg load in sheep

\begin{tabular}{lcc}
\hline \multirow{3}{*}{ Animals } & \multicolumn{2}{c}{ Mean Worm-Egg Load (EPG) } \\
\cline { 2 - 3 } & $\begin{array}{c}\text { Extensive System (free range grazing) with } \\
\text { irregular drenching schedules }\end{array}$ & $\begin{array}{c}\text { Semi-Intensive System (Paddock grazing) with regular } \\
\text { but routine drenching schedules }\end{array}$ \\
\hline \multirow{2}{*}{ Lambs } & $9813^{*}$ & $1612^{*}$ \\
& $(96)$ & $(83)$ \\
\hline \multirow{2}{*}{ Adults } & $763^{* *}$ & $335^{* *}$ \\
& $(102)$ & $(78)$
\end{tabular}

Assoku (1981) Figures in brackets are the total number of animals examined in each group.

*- Differences are significant, **- at significant $1 \%(\mathrm{P}<0.01)$.

\subsection{Host Factors}

Host factors such as age, breed, nutrition, physiological state and presence or absence of inter-current infections also influence the incidence rate and severity of infection with GI nematodes in sheep and goats (Assoku, 1981; Kusiluka \& Kambarage, 1996). Kids and lambs are known to be more vulnerable compared to adults and worm burdens decrease with increasing age (Goldberg, 1952; Paver et al., 1955; Edwards \& Wilson, 1958; Brunsdon, 1962; Assoku, 1981; Kusiluka \& Kambarage, 1996). Clinical parasitic gastroenteritis has been reported in young animals whilst infections in mature animals are generally subclinical in nature (Chiejina, 1986). The lower prevalence in adults has been attributed to immunological maturity as the animals grow and the increase in acquired resistance due to repeated exposure (Chiejina, 1986). Some breeds of sheep and goats are known to be genetically resistant to gastrointestinal nematodes infections than others. For instance, in Ghana, the local breeds, the West African dwarf sheep and the West African Long-legged sheep have both been shown to be more resistant to Haemonchus than the non indigenous Nungua Black-head (NBH) sheep (Assoku, 1981). It has also been demonstrated that within breeds, some lambs are naturally more resistant to T. colubriformis, for instance, and have lower worm burdens and reduced production losses than those of normal susceptibility (Windson, 1990). This information is important in breeding programmes to reduce the use of anthelmintics.

Another host factor known to influence nematode infections in small ruminants is the periparturient egg rise- a temporary loss of naturally acquired immunity to gastrointestinal parasites that begins approximately two weeks before parturition and continues for up to eight weeks after (Schoenian, 2012). During the period the females are readily infected and existing worm burdens become more active resulting in a sudden increase in worm eggs passed in the faeces and an increase in infectious L3 larvae on the pasture during late pregnancy and lactation. Lambs and kids are very susceptible to worms and thus particularly at risk (Hunter, 1996; Schoenian, 2012). It has been documented that increasing the protein level of the diet near kidding or lambing could significantly contribute to alleviate the increase in faecal egg excretion usually observed in ewes and does around the end of gestation and start of lactation (Etter et al., 1999; Hoste et al., 2005). The periparturient egg rise is believed to be the result of 
various nutritional and hormonal factors and its intensity and distribution varies by breed, individual and season (Schoenian, 2012)

Generally poor nutrition decreases the resistance of sheep and goats thus improving the establishment of worm burdens and increasing the pathogenicity of the parasites. Therefore, worm burdens tend to be higher in poorly- fed animals than in well-fed animals. Malnutrition during the dry season has been found to lower the resistance of goats and sheep to $H$. contortus infections resulting in heavy mortalities while restricted feeding due to tethering during the rainy season has been associated with higher nematode burdens and mortality of goats in some parts of sub-Saharan Africa. Health status of the host and other stress factors also enhance the establishment of higher worm burdens (Kassai, 1999; Taylor et al., 2007).

\section{Impact on Production}

The pathological features of gastrointestinal nematode infections vary. Most of the nematodes however are capable of producing diarrhoea and loss of condition when present in sufficient numbers (Anderson et al., 1965; Blood et al., 1979) and some species such as Haemonchus contortus, are blood suckers and cause anaemia (Urquhart et al., 1996). The clinical signs of the most important gastrointestinal nematodes of ruminants are shown in Table 4. Clinical signs depend on a number of factors such as nutritional status of the animal, the level of infection and the species of helminths (Hunter, 1996).

The most noticeable effect of helminth infections in small ruminants in tropical Africa is death of the host (Wanyangu et al., 1994). Mortality rates may exceed 40\% whilst weight loss of 0.6-1.2/year/animal may occur (IEMVT, 1980). Subclinical and chronic conditions resulting from reduced feed intake and decreased feed utilization efficiency are believed to be the major economic losses caused by helminth infections (Holmes, 1993).

Table 4. Gastrointestinal nematodes of ruminants

\begin{tabular}{l}
\hline Stomach worms \\
\hline Haemonchus spp. \\
Ostertagia spp. \\
Trichostronglyus axei \\
\hline Worms of the small \\
intestines
\end{tabular}

Trichostronglyus spp

Blood sucking worms that can cause anaemia and weight loss; very important in areas that are permanently warm and humid or have prolonged warm rainy season.

Causes gastritis, diarrhoea and weight loss; important in sub-tropical climates with winter rainfall.

Cooperia spp

Similar but lesser effect to Ostertagia spp

Nematodirus spp

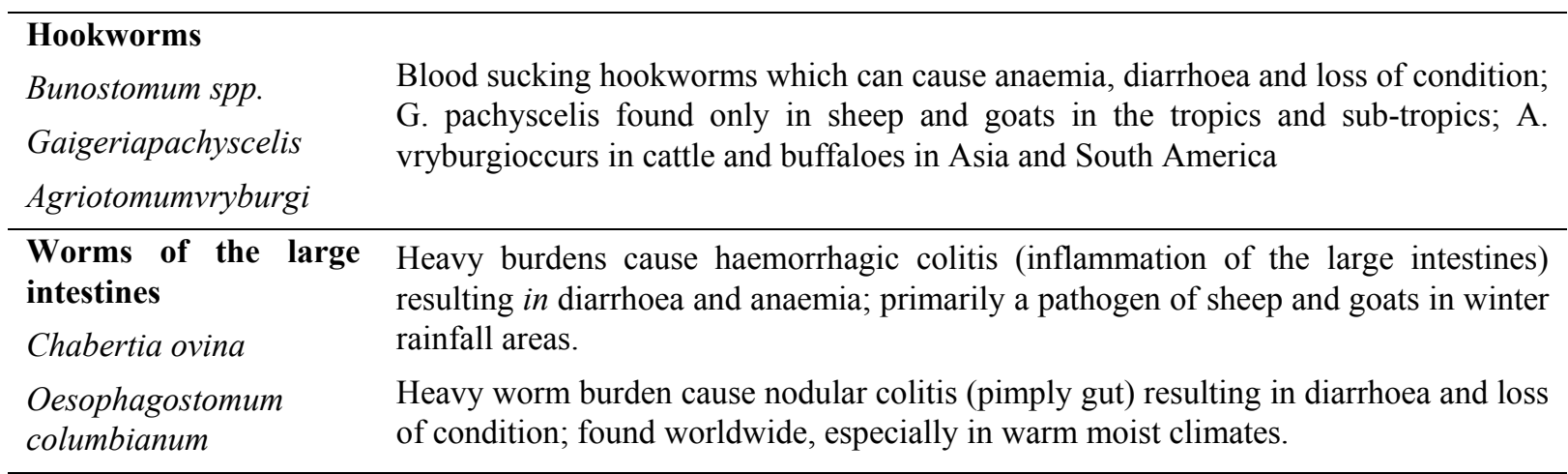

Adapted from Hunter, 1996.

Anthelmintic treatment is the most common way of controlling nematode infections in small ruminant particularly in institutional and commercial farms in Ghana. However, several countries have reported anthelmintic resistance, representing a limitation for sustainable small ruminant production (Domke et al., 2011). Improvements in the management systems and husbandry practices coupled with strategic deworming when conditions are most 
favourable for larval development on pasture could be a more sustainable way of improving small ruminant production in Ghana.

\section{Conclusion}

Twelve nematode species belonging to six families have been reported to infect sheep and goats in Ghana. Haemonchus, Trichostronglyus, Oesophagostomum and Cooperia are the principal genera (Agyei \& Amponsah, 2001). Rainfall is considered the main climatic factor determining the availability of infective strongylid larvae and the transmission of infection in grazing animals. However, management systems, and host factors such as age, breed, nutrition and health of the host also influence the incidence rate and severity of infection. Epidemiological knowledge is crucial to the development of a comprehensive and sustainable strategy for controlling gastrointestinal nematode infections in sheep and goats in the different agro-ecological zones and management systems in Ghana.

\section{References}

Agyei, A. D. (1991). Epidemiological observations on helminth infections of calves in southern Ghana. Tropical animal health and production, 23(3), 134-140. http://dx.doi.org/10.1007/BF02356991

Agyei, A. D. (1997). Seasonal changes in the level of infective strongylate nematode larvae on pasture in the coastal Savanna regions of Ghana. Veterinary Parasitology, 70 , 175-182. http://dx.doi.org/10.1016/S0304-4017(96)01101-6

Agyei, A. D. (2003). Epidemiological studies on the gastrointestinal parasitic infection of lambs in the Coastal Savanna regions of Ghana. Tropical Animal Health and Production, 35, 207-217. http://dx.doi.org/10.1023/A:1023339328589

Agyei, A. D., \& Amponsah, A., (2001). Seasonal availability of infective strongylate nematode larvae on pasture in the forest zone of Ghana. Bulletin of Animal Health and Production in Africa, 49, 68-72.

Agyei, A. D., Aklaku, I. K., Debra, S. O., Djang-Forjour, K. T., Dodoo, R., \& Fynn, K. (2006). Epidemiological studies on the gastrointestinal parasitic infection of lambs in the Guinea and transitional savanna regions of Ghana. Ghana journal of agricultural science, 38(2), 135-144. http://dx.doi.org/10.4314/gjas.v38i2.2109

Allonby, E. W., \& Urquhart, G. M. (1975). The epidemiology and pathogenic significance of haemonchosis in a Merino flock in East Africa. Veterinary Parasitology, 1, 129-143. http://dx.doi.org/10.1016/0304-4017(75)90015-1

Anderson, N., Armour, J., Jarrett, W. F., Jennings, F. W., Ritchie, J. S., \& Urquhart, G. M. (1965). A field study of parasitic gastritis in cattle. Veterinary Record, 77, 1196-1204. http://dx.doi.org/10.1136/vr.77.41.1196

Assoku. R. K. G. (1981).Studies on the parasitic helminths of sheep and goats in Ghana. Bulletin of Animal Health and Production in Africa, 29, 1-10

Barger, I. A., \& Southcott, W. H. (1975).Control of nematode parasites by grazing management. I. Decontamination of cattle pastures by grazing with sheep. International Journal of Parasitology, 5, 39-44. http://dx.doi.org/10.1016/0020-7519(75)90095-8

Beal, W. P. (1929). Reports on the Department of Animal Health, Gold Coast for 1927-1928, Accra: Govt. Printer.

Bekele, T., Woldeab, T., Lahlou-Kassi, A., \& Sherington, J. (1992). Factors affecting morbidity and mortality on-farm and on station in the Ethiopian highland sheep. Acta Tropica, 52, 99-109. http://dx.doi.org/10.1016/0001-706X(92)90025-S

Benneh, G., Agyepong, G. T., \& Allotey, J. A. (1990).Land degradation in Ghana. Food Production and Rural Development Division. Commonwealth Secretariat, Marlborough House. Pall Mall. London.

Blood, D. C., Henderson, J. A., \& Radostits, O. M. (1979). Veterinary Medicine (5th ed.). London: Bailliere Tindall.

Brunsdon, R. V. (1962). Age resistance of sheep to infestation with the nematodes, Nematodiru filicolis and Nematodirus spathtiger. New Zealand. Veterinary Journal, 10, 1-6. http://dx.doi.org/10.1080/00480169.1962.33448

Chiejina, S. N. (1986). The epidemiology and control of parasitic gastroenteritis of domesticated ruminants in Nigeria.Helminthology.Abstracts Ser A, 55, 413-429. http://dx.doi.org/10.1007/BF00346720

Chiejina, S. N., Fakae, B. B., \& Eze, P. L. (1989).Development of and survival and survival of free-living stages of gastrointestinal nematodes of sheep and goats on pasture in the Nigerian derived Savanna. Veterinary 
$\begin{array}{llll}\text { Research } \quad \text { Communications, } & \text { 13, } & \text { Retrieved } & \text { from }\end{array}$ http://link.springer.com/content/pdf/10.1007/BF00346720.pdf

Demeler, J. (2005). The Physiological Site of Action and the Site of Resistance to the Macrocyclic Lactone Anthelmintics in Sheep Parasitic Trichostrongyloid Nematodes. Hannover: Tierärztliche Hochschule Hannover. Retrieved from http://elib.tiho-hannover.de/dissertations/demelerj_ws05.pdf

Dickson, K. B., \& Benneh, G. (1988). A new geography of Ghana. Longman Group UK Limited. Longman House, Burnt Mill, Harlow, Essex, England

Dolu, C. K. (1972). Dissertation Abstracts Department of Animal Science. University of Ghana, Legon., Ghana.

Domke, A. V. M., Chartier, C. Gjerde, B., Leine, N., Vatn, S., Østerås, O., \& Stuen, S. (2011). Worm control practice against gastro-intestinal parasites in Norwegian sheep and goat flocks. Acta Veterinaria Scandinavica, 53, 29. http:dx.doi.org/10.1186/1751-0147-53-29

Durie, P. H. (1962). Seasonal fluctuations in populations of strongyle larvae on calf pasture and their significance in infection of the grazing animal. Australian Journal of Agricultural Research, 13, 767-777. http://dx.doi.org/10.1071/AR9620767

Edwards, E., \& Wilson, A. B. (1958).Observations of nematode infections of sheep and goats in West Africa. Journal of Helminthology, 32, 195-210. http://dx.doi.org/10.1017/S0022149X00019738

Etter, E., Chartier, C., Hoste, H., Pors, I., Bouquet, W., Lefrileux, Y., \& Borgida, L. P. (1999). The influence of nutrition on the peripaturient rise in faecal egg counts in dairy goats: results from a 2-year study. Revue de Médecine Vétérinaire, 150, 975-980.

Eysker, M. (1993).The role of inhibited development in the epidemiology of Ostertagia infections. Veterinary Parasitology, 46, 259-269. http://dx.doi.org/10.1016/0304-4017(93)90063-S

Fabiyi, J. P. (1987). Production losses and control of helminths in ruminants of tropical regions. International Journal of Parasitology, 17, 435-540. http://dx.doi.org/10.1016/0020-7519(87)90119-6

Fakae, B. B. (1990). Seasonal changes and hypobiosis in haemonchus contortus infections in the Nigerian derived Savanna.Veterinary Parasitology, 36, 123-130. http://dx.doi.org/10.1016/0304-4017(90)90100-P

FAO. (1992). Distribution and impact of helminth diseases of livestock in developing countries.FAO Animal Production and Health paper, 96. FAO, Rome. Retrieved from http://www.fao.org/docrep/004/t0584e/t0584e00.htm

Goldberg, A. (1952). Journal of Parasitology, 38(35), 35-47. http://dx.doi.org/10.2307/3274170

Hammond, J., \& Sewell, M. M. H. (1991). Helminthology. MSc. /Diploma in Tropical Animal Production and Health. Centre for Tropical Veterinary Medicine, Royal (Dick) School of Veterinary Studies, Edinburgh, Scotland.

Hansen, J. W., \& Perry, B. D. (1994).The Epidemiology, Diagnosis and Control of Helminth Parasites of Ruminants (2nd ed.). Nairobi: International Laboratory for Research on Animal Diseases.

Holmes, P. H. (1993). Interaction between parasites and animal nutrition: the veterinary consequences. Proceedings of the Nutrition Society, 52, 113-120. http://dx.doi.org/10.1079/PNS19930043

Hoste, H., Torres-Acosta, J. F., Paolini, V., Aquilar-Caballero, A., Etter, E., Lefrileux, Y., ... Broqua, C. (2005). Interaction between nutrition and gastrointestinal infections with parasitic nematodes in goats. Small Ruminants Research, 60, 141-151. http://dx.doi.org/10.1016/j.smallrumres.2005.06.008

Hunter, A. (1996). Specific Diseases. In Animal Health (2nd ed., pp. 143-146). London; Macmillan Education Limited.

IEMVT. (1980). Les petits ruminants d'Afrique de l'Ouest. Synthése des connaissances actuelles.

Jackson, C. (1965). List of helminth parasites found in domestic animals of West Africa. Ghana Journal of Science, $5,65-70$

Kassai, T. (1999). Veterinary Helminthology. Oxford, UK. Butterworth Heinemann.

Kusiluka L., \& Kambarage, D. (1996). Diseases of Small Ruminants in sub-Saharan Africa. VETAID. Centre for Tropical Veterinary Medicine, Easter Bush Roslin, Midlothian EH25, Scotland, 1996.

Lee, R. P., Armour, J., \& Ross, J. G. (1960). The seasonal variations in strongyle infestations in Nigeria Zebu cattle.British Veterinary Journal, 116, 1-13. 
Levine, N. D. (1968). Nematode Parasites of Domestic Animals and of Man. Minneapolis: Burgess Publishing Company.

Lichtenfels, J. R., \& Pilitt, P. A. (1989). Cuticular ridge patterns of Marshallagia marshalli and Ostertagia occidentalis (Nematoda: Trichostrongyloidea) parasitic in ruminants of North America. Proceedings of the Helminthological Society of Washington, 56(2), 173-182.

Manfredi, M. T. (2006). Biolgogy of gastrointestinal nematodes of ruminants. Parassitologia, 48(3), 397-401. Retrieved from http://www.ncbi.nlm.nih.gov/pubmed/17176950

Meteorological Services Department, Legon, Accra, Ghana. Rainfall distribution by agro-ecological zones. Retrieved from http//www.fao.org/docrep/008/a0013e/a0013e05.htm

Michel, J. F. (1974). Arrested development of nematodes and some related phenomena. Advances in Parasitology, 12, 279-366. http://dx.doi.org/10.1016/S0065-308X(08)60390-5

Naate, N. M. (1973). Dissertation Abstracts Department of Animal Science. University of Ghana, Legon., Ghana.

Notifor, H. N., Shel, S. J., Ndaleh, N. W., \& Mbunkur, G. N. (2013). Epidemiological studies of gastrointestinal parasitic infections in ruminants in Jakiri, Bui Division, North West of Cameroon. Journal of Veterinary Medicine Animal Health, 5(12), 344-352. Retrieved from http//www.academicjournals.org/JVMAH

Nwafor, C. U. (2004). Anthelmintics use for small ruminant production in The Gambia: a participatory and economic benefit-cost analysis. Livestock Research for Rural Development, 16(9), Retrieved from http://www.lrrd.org/lrrd16/9/nwaf16068.htm

O'Connor, L. J., Walkden-Brown, S. W., \& Kahn, L. P. (2006). Ecology of the free-living stages of major trichostrongylid parasites of sheep. Veterinary Parasitology, 142(1), 1-15. http://dx.doi.org/10.1016/j.vetpar.2006.08.035

Ockling, S. (1987) Position paper on sheep and goat production in Ghana. Sheep and Goat Meat Production in the Humid Tropics of West Africa. FAO Corporate Document Repository. Retrieved from http://www.fao.org/docrep/004/s8374b/s8374b17.htm

Oduro, G. A. (1972). Some common diseases of sheep and goats in Ghana. Proceedings of the Ghana Animal Science Symposium, 5, 61-69.

Ogunsusi, R. A. (1979). Pasture infectivity with trichostrongylid larvae in the Northern Guinea Savanna of Nigeria. Research in Veterinary Science, 26, 320-323. Retrieved from http://europepmc.org/abstract/MED/515519

Okon, E. D., \& Enyenihi, U. D. (1975). Infectivity of Haemonchus contortus and Trichostrogylus colubriformis larvae on pasture at Ibadan, Bulletin, Office International des Epizooties, Paris, 83, 1139-1144. http://dx.doi.org/10.1007/BF02297381

Okon, E. D., \& Enyenihi, U. D. (1977). Development and survival of Haemonchus contortus larvae on pasture in Ibadan.Tropical Animal Health and Production, 9, 7-10. Retrieved from http://link.springer.com/content/pdf/10.1007/BF02297381.pdf

Oppong, E. N. W. (1973). Diseases of sheep in Ghana. Ghana Journal of Agricultural Science, 6, 3-6. Retrieved from http://gains.org.gh/articles/gjas_v6_1_p3_7.pdf

Paver, H., Parnell, I. W., \& Morgan, D. O. (1955). Journal of Comparative Pathology, 65, 220-235. http://dx.doi.org/10.1016/S0368-1742(55)80019-7

Rahmann, G., \& Seip, H. (2006). Alternative strategies to prevent and control endoparasite diseases in organic sheep and goat farming systems - a review of current scientific knowledge. G Rahmann (hrsg.) Ressortforschung für den Ökologischen Landbau, 2006. Retrieved from http://orgprints.org/10030/1/08_Rahmann_Endoparasiten_fertig.pdf

Rey, B. (1991). Small Ruminant genetic resources and parasite challenge in sub-Saharan African. In: Resistance to Endoparasitses in Small Ruminants. Proc. Research Planning Workshop (pp. 23-32). held at ILCA, Addis Ababa, Ethiopia, 1991.

Roeber, F., Jex, R., \& Gasser, R. B. (2013). Impact of gastrointestinal parasitic nematode of sheep, and the role of advanced molecular tools for exploring epidemiology and drug resistance - an Australian perspective. Parasite and Vectors 2013, 6, 153. Retrieved from http://www.parasitesandvectors.com/content/6/1/153 
Sani, R. A., Chong, D. T., Halim, R. A., Chandrawathani, P., \& Rajamanickam, C. (1995). Control of gastrointestinal strongylosis by grazing management. Proceedings of an international Conference on 'Novel approaches to the control of helminth parasites of Livestock', Armidale, Australia.

Schillhorn van Veen, T. W. (1973). Small ruminant health problems in Northern Nigeria with emphasis on helminthiasis. Nigerian Veterinary Journal, 2, 26-31.

Schoenian, S. (2012). Periparturient Egg Rise-American Consortium for Small Ruminant Parasite Control. Retrieved from http://www.acsrpc.org/Resources/Topics/PPER.html

Sprent, J. F. A. (1946). Some observations on the bionomics of Bunostomum phlebotomum, a hookworm of cattle. Parasitology, 37, 202-210. http://dx.doi.org/10.1017/S0031182000013366

Taylor, M. A., Coop, R. L., \& Wall, R. L. (2007). Veterinary Parasitology (3rd ed.). Oxford. UK. Blackwell Publishing.

Thomas, R. L., \& Bell, S. A. (1988). Control gastrointestinal parasitism with a pulse-related anthelmintic device. Veterinary Parasitology, 29, 19-28. http://dx.doi.org/10.1016/0304-4017(88)90004-0

Urquhart, G. M., Armour, J., Duncan, J. L., Dunn, A. M., \&Jennings, F. W. (1996). Veterinary Parasitology, Longman Group, UK Limited.

Wanyangu, S. W., \& Bain, R. K. (1994). The impact of helminth infection on small ruminant production in Tropical Africa. The Kenya Veterinarian, 18(2), 104-106.

Windson, R. G. (1990). Selective breeding for the control of nematodiosis in sheep. Revue Scientifique et Technique, Office International Des Epizootics, 9, 555-576.

\section{Copyrights}

Copyright for this article is retained by the author(s), with first publication rights granted to the journal.

This is an open-access article distributed under the terms and conditions of the Creative Commons Attribution license (http://creativecommons.org/licenses/by/3.0/). 